\title{
Meningkatkan Partisipasi Membaca Dan Menulis Descriptive Siswa Kelas X Ms3 Sman 1 Narmada Dengan Penerapan Model Circ
}

\author{
Lalu Husnul Amrullah
}

\begin{abstract}
Abstrak. Menbaca dan menulis adalah hal yang penting dalam belajar bahasa pada umumnya dan belajar bahasa inggris pada khususnya. Latar belakang penelitian ini didasarkan pada kurangnya partisipasi siswa dalam proses pembelajaran Reading dan Writing. Permasalahan yang sering muncul selama proses pembelajaran tersebut antara lain: (a) Materi/text yang diajarkan dalam reading dan writing berbeda/tidak terpadu dengan materi/text yang diajarkan dalam writing. (b) kemampuan membaca, memahami dan membuat paragraph siswa masih rendah. (c) keterbatasan guru dalam mengarahkan siswa yang big class dan heterogen. (d) keterbatasan waktu yang tersedia yaitu 2 JP pada K13. Penelitian tindakan kelas ini bertujuan untuk mencari penyelesaian dan menindak lanjuti permasalahan tersebut di atas. Adapun solusi pengajaran reading dan writing tersebut adalah pengajaran dengan menggunakan model "COOPERATIVE INTEGRATED READING AND COMPOSITION (CIRC) atau kooperatif terpadu membaca dan menulis. Penelitian ini merupakan penelitian tindakan kelas. Penelitian ini dilaksanakan di SMAN 1 Narmada dengan subjek penelitian kelas X MS3 semester 1 tahun pelajaran 2017/2018 yang berjumlah 36 siswa. Penelitian ini dilaksanakan dalam dua siklus. Data yang dikumpulkan berupa data kuantitatif. Materi yang diajarkan pada penelitian ini adalah descriptive text. Hasil penelitian pada silus 1 menunjukkan jumlah siswa yang berpartisipasi dalam pembelajaran descriptive text sebanyak $61,1 \%$ dengan kategori cukup aktif. Kurangnya partisipasi siswa berpengaruh pada hasil belajar siswa dimana hanya 13,9\% yang mencapai nilai KKM. Dikarenakan belum mencapai target aktif, penelitian ini dilanjutkan ke siklus dua dengan memberikan perbaikan pada siklus sebelumnya. Hasil penelitian pada siklus dua menunjukkan jumlah siswa yang berpartisipasi meningkat menjadi 78,7\% dengan kategori aktif. Selain itu hasil belajar siswa juga meningkat menjadi 63,8\%. Dengan demikian dapat disimpulkan bahwa penerapan model COOPERATIVE INTEGRATED READING AND COMPOSITION (CIRC) dapat meningkatkan partisipasi siswa dalam proses pembelajaran reading dan writing.
\end{abstract}

Key words: $C I R C$, Reading, Writing, Descriptive text

\section{PENDAHULUAN}

Latar belakang penelitian tindakan kelas "Meningkatkan Partisipasi Membaca dan Menulis Descriptive Siswa Kelas X MS3 SMAN 1 Narmada dengan penerapan model CIRC" ini didasarkan pada berbagai masalah yang ditemukan oleh guru dalam selama proses pembelajaran Reading dan Writing. Permasalahan yang sering muncul selama proses pembelajaran tersebut antara lain: (a) Materi/text yang diajarkan dalam reading dan writing berbeda/tidak terpadu dengan materi/text yang diajarkan dalam writing. (b) kemampuan membaca, memahami dan membuat paragraph siswa masih rendah. (c) keterbatasan guru dalam mengarahkan siswa yang big class dan heterogen. (d) keterbatasan waktu yang tersedia yaitu 2 JP pada K13.

Menbaca dan menulis adalah hal yang penting dalam belajar bahasa pada umumnya dan belajar bahasa inggris pada khususnya. Menurut Mary Leonhardt (2002) "membaca dan menulis tak pelak lagi saling berkaitan. Anak-anak yang gemar membaca akan memperoleh rasa kebahasaan tertulis, yang kemudian mengalir kedalam tulisan mereka". Siswa yang suka menulis dan sering menulis, juga lebih memahami hal-hal yang dibacanya. Tumbuhkan kebiasaan dan kecintaan membaca pada diri siswa. Inilah satu-satunya hal terpenting yang bisa dilakukan untuk menjamin agar mereka menjadi penulis yang baik. 
Kegiatan membaca dan menulis dalam pengajaran bahasa asing secara efektif dan efisien sangat penting bagi siswa untuk menjembatani antara peningkatan kemampuan dalam bahasa dan tuntutan belajar sebagai siswa. (Kern dan Schultz dalam O'Brien 2004) mengatakan kegiatan menulis memiliki beberapa tujuan. Adapun tujuan-tujuan tersebut antara lain: (i) meningkatkan kemampuan siswa untuk berfikir secara eksplisit tentang bagaimana mengungkapkan pikiran, perasaan dan ide sehingga dapat diterima oleh pembaca. (ii) mengukur kemampuan siswa dalam mengukur bahasa baru. (iii) memberikan peluang kepada siswa untuk memproses makna. (iv) memberi peluang bagi siswa untuk berkreativitas dalam rangka mempersiapkan diri untuk mampu membaca teks dan artikel secara efektif dan efisien.

Menurut John T Guthrie, Allan Wigfield dan Kathleen c Perencevich dalam bukunya yang berjudul Motivating Reading Comperhension dan menggunakan istilah consep oriented reading instruction (CORI) mengatakan bahwa karakteristik kelas itu sangat membantu perkembangan minat membaca. Karakteristik kelas mengajak siswa untuk termotivasi membaca atau tidak, jadi atmosfir di kelas sangat penting. John $\mathrm{T}$ Guthrie juga mengatakan bahwa comprehending dan integrating skills itu penting karena memadukan membaca dengan skills yang lain banyak manfaat yang didapat. Disini ia memadukan reading dengan science. Siswa memadukan teks yang dipelajari dengan science yang pernah dilihat, dibaca, didengar, atau menulis laporan tentang apa yang didapat dari teks tersebut.

Berdasarkan uraian diatas, penelitian ini mencoba menekankan pada proses untuk meningkatkan motivasi siswa dengan menerapkan cooperative integrated reading and composition (kooperatif terpadu membaca dan menulis). Dengan menerapkan model ini, siswa akan mampu membaca dan menulis, mampu berkolaborasi dengan temannya, mampu membuat teks atau tulisan dengan kata-kata mereka sendiri dan berani tampil percaya diri.

\section{Metode Penelitian}

Jenis penelitian ini adalah peneltian tindakan kelas (Classroom action research) bersifat partisipan. Maksudnya bahwa orang yang akan melakukan tindakan harus juga terlibat dalam proses penelitian dari awal. Penelitian tindakan kelas ini menggunakan model penelitian tindakan yang dikemukakan oleh Kemmis dan Teggart (Suwarsih Madya, 1994: 27).

Adapun proses penelitian tindakan model Kemmis dan Teggart adalah: (a) perencanaan pertama; (b) tindakan pertama ; (c) pengamatan pertama (observe I); (d) refleksi pertama ; (e) revisi terhadap perencanaan pertama ; (f) tindakan ke dua (observe 2); dan (g) refleksi ke dua.

\section{Setting dan subyek penelitian:}

Penelitian ini dilaksanakan di SMAN 1 narmada dengan melibatkan siswa kelas X MS3 semester 1 tahun pelajaran 2017/2018 yang berjumlah 36 orang.

\section{Instrumen penelitian:}

Untuk memperoleh data yang lebih akurat, teknik yang digunakan dalam pengumpulan data adalah: (a) Lembar observasi; (b) presentasi; (c) wawancara; dan (d) dokumentasi.

\section{Sumber dan tekhnik pengumpulan data:}

Adapun sumber data pada penelitian ini yaitu: (a) Lembar observasi aktivitas siswa; (b) hasil wawancara; (c) data dokumentasi; dan (d) rubrik presentasi. Tekhnik pengumpulan data pada penelitian ini dilakukan dengan metode observasi dan wawancara.

\section{Tekhnik analisis data dan kriteria keberhasilan}

Data yang terkumpul dianalisi secara kuantitatif. Analisis kuantitatif digunakan untuk mendeskripsikan hasil yang dicapai siswa. Selanjutnya dari hasil tersebut akan dilakukan refleksi untuk menemukan kelemahan dari tindakan yang dipilih kemudian menentukan tindakan untuk perbaikan siklus sebelumnya 
yang akan dilakukan pada siklus selanjutnya.

a. Data hasi wawancara dan observasi siswa

Data kuantitatif hasil observasi belajar siswa pada penelitian ini berupa persentase jumlah siswa yang aktif / berpartisipasi. Untuk menghitung persentase keaktifan siswa dihitung dengan menggunakan rumus: $\mathrm{M}=\frac{K}{\mathrm{~N}} \times 100 \%$

Keterangan:

$\mathrm{M} \quad$ = persentase jumlah siswa yang aktif

$\sum X \quad=$ jumlah siswa yang aktif

$\mathrm{N} \quad=$ jumlah seluruh siswa kelas $\mathrm{X}$ MS1

b. Data kegiatan siswa

Untuk menentukan penilaian terhadap kegiatan / keaktifan siswa digunakan kriteria sebagai berikut:

(1) Sangat aktif : apabila lebih dari $80 \%$ siswa memenuhi indikator yang telah ditentukan.

(2) Aktif : apabila 70-80 \% siswa memenuhi indikator yang telah ditetapkan.

(3) Cukup aktif : apabila 50-69 \% siswa memenuhi indikator yang telah ditetapkan

(4) Kurang aktif : apabila $<50 \%$ siswa memenuhi indikator yang tela ditetapkan.

c. Indikator keberhasilan

Yang menjadi tolak ukur keberhasilan penelitian ini antara lain adalah adanya peningkatan partisipasi siswa minimal mencapai kriteria aktif (70-80\% siswa berpartisipasi).

\section{Prosedur penelitian}

Penelitian ini dilaksanakan dalam dua siklus. Untuk mengetahui kemampuan siswa dalam reading dan writing, ada beberapa langkah-langkah yang ditempuh pada setiap siklus. Langkah-langkah tersebut meliputi:

Perencanaan

Mendesain rencana pelaksanaan pembelajaran (RPP)
Mendesain rancangan evaluasi

Mendesain materi yang menggunakan model CIRC

Membuat skenario pembelajaran

Membuat lembar observasi

Pelaksanaan tindakan observasi. Kegiatan ini merupakan pelaksanaan dari skenario pembelajaran yang telah dirancang sekaligus mengadakan observasi dari tindakan yang dilaksanakan.

Analisis dan refleksi

Hasil tanggapan terhadap wacana atau kliping dan tulisan pada lembar kertas dituangkan kedalam tiga model ini. Diobservasi, dipresentasikan, dikumpulkan dan dianalisis pada siklus yang pertama untuk mengetahui apakah tindakan yang dilakukan mampu meningkatkan motivasi dan partisipasi siswa dalam pembelajaran reading dan writing pada pembelajaran descriptive text.

Adapun prosedur penelitian PTK ini dapat dilihat pada bagan alir berikut:

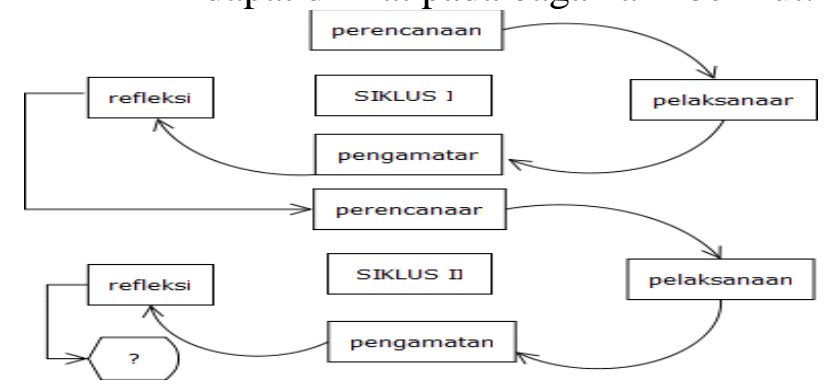

Hasil dan Pembahasan

Siklus I diawali dengan melaksanakan Rencana Pelaksanaan Pembelajaran pada pertemuan I dan II. Adapun rincian kegiatan belajar mengajar (KBM) sebagai berikut: 


\begin{tabular}{|c|c|c|}
\hline Pertemuan & Kegiatan guru & Kegiatan siswa \\
\hline $\begin{array}{l}\text { Pertemuan pertama } \\
\text { Selasa, } 14 \text { Agustus } \\
\text { 2017 }\end{array}$ & $\begin{array}{l}\text { Mengelompokkan siswa yang } \\
\text { anggotanya } 4 \text { orang. } \\
\square \begin{array}{l}\text { Membagikan topik wacana } \\
\text { descriptive teks }\end{array} \\
\square \begin{array}{l}\text { Berkeliling membimbing } \\
\text { siswa }\end{array}\end{array}$ & $\begin{array}{l}\text { Bekerjasama saling } \\
\text { membacakan dan menemukan } \\
\text { ide pokok dan member } \\
\text { tanggapan terhadap wacana } \\
\text { dengan topik descriptive teks } \\
\text { dan ditulis pada lembar kertas }\end{array}$ \\
\hline $\begin{array}{l}\text { Pertemuan ke dua } \\
\text { Selasa, } 29 \text { Agustus } \\
2017\end{array}$ & $\begin{array}{l}\text { Membuat kesimpulan bersama } \\
\text { siswa tentang tulisan dan } \\
\text { bacaan descriptive. } \\
\square \text { Memberi feedback dan } \\
\text { komentar tentang apa yang } \\
\text { harus diperbaiki dari tulisan } \\
\text { siswa } \\
\square \text { Memberikan project kepada } \\
\text { masing-masing kelompok } \\
\text { (hari dan tanggal pengerjaan } \\
\text { project ditulis) } \\
\square \text { Mengamati memonitor } \\
\text { pengerjaan project } \\
\square \text { Membahas hasil project } \\
\end{array}$ & $\begin{array}{l}\text { Mempresentasikan hasi } \\
\text { tulisan kelompok } \\
\text { masing-masing } \\
\square \text { Menganalisa tulisan kelompok } \\
\text { yang didengarnya } \\
\square \text { Menulis kesalahan-kesalahan } \\
\text { kelompok lain } \\
\square \text { Membuat kesimpulan } \\
\square \text { Mengerjakan project yang } \\
\text { diberikan oleh guru }\end{array}$ \\
\hline
\end{tabular}

Rekapitulasi hasil lembar observasi siswa pada siklus I diperoleh data yang terlihat pada Tabel 2 berikut ini

Tabel 2. Rekapitulasi Hasil Observasi Kegiatan Siswa Siklus I
\begin{tabular}{|c|c|c|c|c|}
\hline \multirow{2}{*}{ Indikator } & \multicolumn{2}{|c|}{ Pertemuan } & Rata-rata & persentase \\
\cline { 2 - 3 } & Pertama & Kedua & & \\
\hline \begin{tabular}{|l|l|l|} 
1. Antusias siswa \\
mengikuti \\
pelajaran
\end{tabular} & 20 orang & 22 orang & 21 orang & $58,3 \%$ \\
\hline $\begin{array}{l}\text { 2. Interaksi siswa } \\
\text { dengan siswa }\end{array}$ & 18 orang & 22 orang & 20 orang & $55,5 \%$ \\
\hline $\begin{array}{l}\text { 3. Interaksi siswa } \\
\text { dan guru }\end{array}$ & 24 orang & 26 orang & 25 orang & $69,4 \%$ \\
\hline total & & & 22 & $61,1 \%$ \\
\hline
\end{tabular}

Dari tabel 2 dapat dilihat bahwa aktivitas pada siklus 1 dikategorikan cukup aktif. Hasil observasi dan evaluasi pada siklus 1 menunjukkan bahwa indikator yang ingin dicapai belum terpenuhi karena belum sampai ke tingkat siswa aktif. Dengan demikian dalam penelitian ini masih perlu dilakukan perbaikan dari kekurangan-kekurangan pada siklus 1 .

Pada pertemuan pertama pembelajaran dimulai dengan membuat kelompok, satu kelompok terdiri dari 4 orang. Disini guru mengalami kesulitan dalam menentukan anggota kelompoknya karena dalam model yang akan diterapkan ini harus secara heterogen. Setelah selesai membuat kelompok, kemudian siswa diberi wacana dengan topik descriptive teks dan guru berkeliling memonitor siswa yang bergiliran membacakan teks dan menjawab pertanyaan di kelompoknya masing-masing. Disini peneliti menemukan masalah. Masalah tersebut antara lain: (a) masih banyak siswa yang belum menunjukkan antusias dan partisipasi dalam berdiskusi dan berintegrasi dengan siswa yang lain. (b) Masih banyak siswa yang bingung karena masih belum paham bacaan atau wacana yang dipelajari terutama kosakata baru yang ada di dalam teks. (c) Hampir semua tulisan siswa masih sama antara kelompok satu dengan kelompojk yang lain. (d) Ada juga kelompok yang sama sekali tidak merespon bacaan dan sebaliknya ada juga dalam satu kelompok itu yang semuanya antusias dan bisa menyelesaikan tugasnya dengan cepat.

Jadi dalam tahapan ke tiga model ini masih banyak siswa yang belum berpartisipasi mengikuti pelajaran. Bisa dikatakan hampir separuh siswa di dalam kelas yang tidak aktif. Masalah juga timbul ketika guru juga menyuruh siswa latihan untuk membacakan hasil tulisan kelompok masing - masing. Yang mau mengikuti hanya sebagian kelompok saja, sedangkan kelompok lain ada yang menunggu dipaksa guru ada juga yang tidak mau sama sekali. Hal ini disebabkan karena: (a) Masih banyak siswa yang masih ragu atau takut mengemukakan ide atau jawaban dari pertanyaan. (b) Banyak siswa yang belum bisa menyusun kalimat sesuai dengan tata bahasa dalam bahasa inggris. (c) Kelompok belum heterogen $100 \%$. (d) Dalam membuat teks deskriptif siswa masih bekerja sama atau mencontek pekerjaan kelompok lain. (e) Masih banyak siswa yang belum mampu menyampaikan dengan baik karena malu atau kurang percaya diri.

Sampailah langkah ke empat pada model ini yaitu siswa mempresentasikan hasil tulisannya di depan kelas. Langkah tersebut dilaksanakan pada pertemuan ke dua pada siklus 1 .

Pada pertemuan kedua diawali dengan siswa mempresentasikan hasil tulisannya di depan kelas. Mulanya presentasi berjalan dengan lancar, ada kelompok yang maju pada pertama kali, kedua, ketiga, dst. Tetapi stelah kelompok yang maju setengahnya dari jumlah kelompok yang ada kegiatan jadi macet dan tidak jalan. Hal ini karena permasalahan yang peneliti sebutkan sebelumnya yaitu : Masih banyak 
siswa yang ragu, yang takut, tidak percaya diri dan belum menguasai tata bahasa dan juga belum mampu menyampaikan tulisannya dengan baik. Pertemuan kedua ini juga melaksanakan langkah kedua berikutnya dari model CIRC ini, adapun langkah tersebut adalah: (a) Guru dan siswa membuat kesimpulan bersama. (b) Penutup. Disini guru menyampaikan kalimat-kalimat yang harus dikoreksi dengan memberi kesempatan siswa untuk membantu mengoreksi kesalahan-kesalahan siswa tersebut. Guru juga menyampaikan atau menyimpulkan tanggapan yang benar tentang wacana tersebut. Langkah ini hampir sebagian besar didominasi oleh guru, hanya sebagian kecil saja siswa yang berpartisipasi aktif. Sampailah ke langkah terakhir dari model ini. Penutupan, dalam menutup pembahasan topik ini guru memberi feedback dengan memberi pertanyaan-pertanyaan terhadap siswa kemudian mengevaluasi tentang topik tersebut. Hasil evaluasi pada siklus pertama ini tidak memuaskan seperti yang terlihat di tabel sebelumnya. Ternyata masih banyak siswa yang belum mencai KKM dan rata-rata aktivitas siswa pada siklus pertama ini hanya mencapai 61,1\% (kategori cukup aktif). Berdasarkan hasil observasi aktivitas belajar siswa dan komentar observer pada siklus 1 didapat masih banyak kekurangan dalam proses belajar mengajar. Itu terbukti dari banyaknya siswa yang belum mencapai kriteria ketuntasan minimum (KKM) dan hanya ada 22 siswa dari 36 siswa yang aktif di dalam kelas selama terjadi proses belajar mengajar. Ini berarti hanya $61,1 \%$ siswa yang berpartisipasi aktif dari $100 \%$ siswa yang ada. Sehingga hal tersebut digolongkan dalam kategori cukup aktif.

Karena tujuan dari penelitian ini untuk meningkatkan motivasi atau partisipasi siswa belajar lebih aktif maka penelitian dilanjutkan pada siklus 2. Pada siklus 2 ini guru melakukan perbaikan-perbaikan dari kekurangan-kekurangan di siklus 1 terutama pada kegiatan guru dan siswa yang harus ditambah supaya siswa lebih aktif dari sebelumnya.

\section{Siklus 2}

Siklus 2 dilaksanakan dua kali pertemuan. Materi yang dibahas adalah descriptive teks. Dalam siklus 2 ini peneliti tetap mengajarkan reading dan writing di pokok bahasan berikutnya agar jam efektif siswa tidak hilang selama kegiatan penelitian. Supaya partisipasi siswa lebih meningkat di siklus 2 ini perlu ditambahkan gambar-gambar dan hadiah sebagai media dan meningkatkan motivasi pembelajaran. Kegiatan belajar mengajar dapat dilihat pada tabel 3. berikut.

Tabel 3 Kegiatan Siklus 2

\begin{tabular}{|c|c|c|}
\hline Pertemuan & Kegiatan guru & $\begin{array}{c}\text { Kegiatan } \\
\text { siswa }\end{array}$ \\
\hline $\begin{array}{l}\text { Pertama } \\
\text { Selasa, } 12 \\
\text { september } \\
2017\end{array}$ & $\begin{array}{l}\text { Guru } \\
\text { bertanya } \\
\text { tentang } \\
\text { beberapa } \\
\text { hal yang } \\
\text { berkaitan } \\
\text { dengan } \\
\text { topik yang } \\
\text { dibahas } \\
\text { Guru } \\
\text { mengelomp } \\
\text { okkan } \\
\text { siswa tiap } \\
\text { kelompok } \\
\text { terdiri dari } \\
4 \\
\text { secara orang } \\
\text { heterogen } \\
\text { Guru } \\
\text { memberi } \\
\text { wacana } \\
\text { dengan } \\
\text { topik } \\
\text { descriptive } \\
\text { teks } \\
\text { Guru } \\
\text { menawarka } \\
\mathrm{n} \\
\text { untuk maju } \\
\text { ke depan } \\
\text { kelas }\end{array}$ & $\begin{array}{l}\text { Siswa } \\
\text { bekerjasa } \\
\text { ma saling } \\
\text { membaca } \\
\text { kan teks } \\
\text { Siswa } \\
\text { membaca } \\
\text { wacana di } \\
\text { depan } \\
\text { kelas dan } \\
\text { siswa lain } \\
\text { meniruka } \\
\text { nnya } \\
\text { Siswa } \\
\text { bekerjasa } \\
\text { ma saling } \\
\text { membant } \\
\text { u } \\
\text { mengerja } \\
\text { kan atau } \\
\text { menjawab } \\
\text { pertanyaa } \\
\text { n-pertany } \\
\text { aan } \\
\text { Siswa } \\
\text { mendisku } \\
\text { sikan } \\
\text { jawaban } \\
\text { bersama } \\
\text { guru } \\
\text { Siswa }\end{array}$ \\
\hline
\end{tabular}




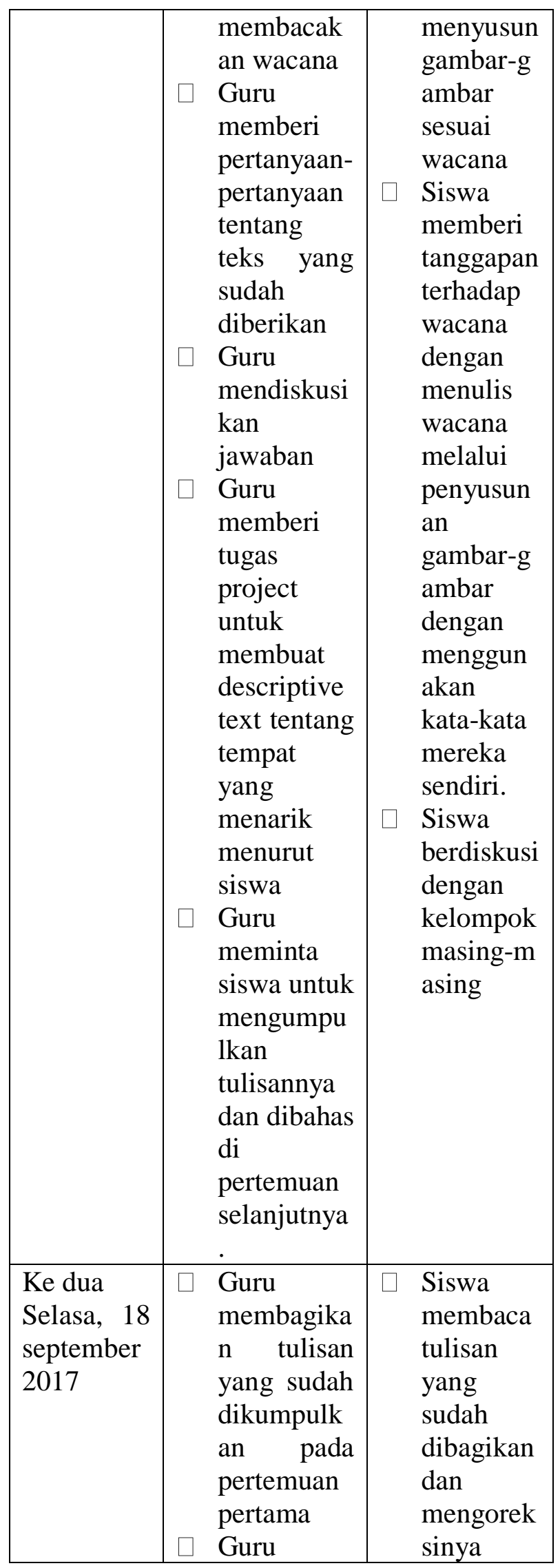

\begin{tabular}{|c|c|c|}
\hline & $\begin{array}{l}\text { menyuruh } \\
\text { siswa } \\
\text { mempresen } \\
\text { tasikan } \\
\text { tugas } \\
\text { projectnya } \\
\text { dengan } \\
\text { cara } \\
\text { mengundi } \\
\text { siapa yang } \\
\text { harus maju } \\
\text { pertama, } \\
\text { kedua, dst. } \\
\text { Guru } \\
\text { memberi } \\
\text { hadiah } \\
\text { kepada } \\
\text { siswa yang } \\
\text { mau maju } \\
\text { presentasi } \\
\text { Guru } \\
\text { membuat } \\
\text { kesimpulan } \\
\text { dan } \\
\text { mengoreksi } \\
\text { tulisan } \\
\text { siswa } \\
\text { Guru } \\
\text { memberi } \\
\text { feedback } \\
\text { terhadap } \\
\text { hasil yang } \\
\text { sudah } \\
\text { dipelajari } \\
\text { siswa } \\
\text { Guru } \\
\text { memberi } \\
\text { soal-soal } \\
\text { evaluasi }\end{array}$ & $\begin{array}{l}\text { Siswa } \\
\text { membaca } \\
\text { hasil } \\
\text { tugas } \\
\text { projectny } \\
\text { a di depan } \\
\text { kelas dan } \\
\text { siswa } \\
\text { yang lain } \\
\text { mengorek } \\
\text { si tulisan } \\
\text { yang } \\
\text { salah } \\
\text { Siswa } \\
\text { membuat } \\
\text { kesimpula } \\
\text { n bersama } \\
\text { guru } \\
\text { Siswa } \\
\text { mengerja } \\
\text { kan } \\
\text { evaluasi }\end{array}$ \\
\hline
\end{tabular}




\begin{tabular}{|c|c|c|c|c|}
\hline \multirow[t]{2}{*}{ Indikator } & \multicolumn{2}{|c|}{ Pertemlatan } & \multirow[t]{2}{*}{ Rata-1ata } & \multirow[t]{2}{*}{ persentase } \\
\hline & Pertama & Kedua & & \\
\hline $\begin{array}{l}\text { 1. Antusias siswa } \\
\text { mengikuti } \\
\text { pelajaran }\end{array}$ & 26 orang & 28 orang & 27 orang & $75 \%$ \\
\hline $\begin{array}{l}\text { 2. Interaksi siswa } \\
\text { dengan siswa }\end{array}$ & 26 orang & 30 orang & 28 otang & $77,8 \%$ \\
\hline $\begin{array}{l}\text { 3. Interaksi siswa } \\
\text { dan guru }\end{array}$ & 30 otang & 30 orang & 30 orang & $83,3 \%$ \\
\hline total & & & 28,3 & $78,7 \%$ \\
\hline
\end{tabular}

Dari tabel 4 dapat dilihat pada siklus 2 aktivitas siswa diperoleh persentase rata-rata $78,7 \%$. Lembar observasi siswa siklus 2 menunjukkan aktivitas belajar siswa meningkat dari siklus sebelumnya dengan rata-rata 78,7\% yang masuk adalam kategori aktif. Menurut Mary Leonhardt membaca dan menulis itu saling berkaitan karena anak yang membaca dan mendapat rasa kebahasaan yang tertulis yang kemudian akan mengalir kedalam tulisna mereka. Dengan demikian pembelajaran yang terpadu antara reading dan writing akan membuat siswa suka membaca dan punya antusiasme untuk menulis apa yang mereka baca. Sesuai dengan CORI (concept oriented reading instrument) menjelaskan bahwa dengan motivasi, kemampuan membaca dan integrasi adalah esensi dari motivasi itu sendiri. Dan memadukan membaca dengan skills yang lain itu membantu siswa mau membaca dan menjadi pembaca, dari membaca siswa dapat informasi untuk dikembangkan melalui skill menulis dan berbicara atau skill yang lain.

Hasil Wawancara

Wawancara dilakukan dengan memanggil siswa satu per satu, kemudian siswa yang sudah diwawancarai dipisah dengan siswa yang belum, dengan tujuan mereka tidak akan saling memberi tahu tentang pertanyaan-pertanyaan yang sudah diberikan guru kepada siswa berikutnya. Hal ini dilakukan agar jawaban siswa bersifat spontan dan apa adanya (tidak dibuat).

Dari hasil wawancara tersebut (instrumen bisa dilihat di lampiran) dapat disimpulkan sebagai berikut:

1. Hampir semua siswa menyatakan senang dengan penerapan model CIRC karena mereka merasa lebih nyaman bekerja melalui kegiatan berkelompok secara berkelompok. Banyak siswa yang merasa terbantu dengan berkelompok secara heterogen ini.

2. Kesulitan yang dirasakan oleh sebagian siswa adalah merangkai kata-kata menjadi kalimat yang benar menurut tata bahasa.

3. Siswa menyarankan agar: (a) waktunya ditambah agar bisa memutar cerita atau semua bisa dapat maju ke depan kelas, (b) mempresentasikan wacananya tidak hanya membaca tapi juga pertunjukkan, di dalam atau di luar kelas.

\section{KESIMPULAN}

Berdasarkan analisis data dan pembahasan hasil penelitian, maka dapat disimpulkan bahwa:

1. Penerapan model cooperative integrated reading and composition (CIRC) dalam proses belajar mengajar di kelas menggunakan 6 langkah yaitu: (1) Membentuk kelompok yang anggotanya 4 orang secara heterogen. Membagikan wacana atau kliping. (3) Siswa bekerja sama saling membacakan dan menemukan ide pokok dan memberi tanggapan terhadap wacana dan ditulis pada selembar kertas.

Mempresentasikan atau membacakan hasil kelompok. (5) guru membuat kesimpulan bersama siswa. (6) Penutup.

2. Penerapan model CIRC dapat meningkatkan partisipasi belajar siswa kelas X MS3 semester 1 SMAN 1 Narmada tahun ajaran 2017/2018.

\section{Daftar Pustaka}

Coxk, E and Guthrie, John T. 2001. Clasroom Motivation and Enggagement in Reading

Guthrie, John T. 2000. Clasroom Contexts from Enggaged Reading and Overview. University of Maryland. USA

Leonhardt, M. 2002. 14 Langkah Jitu Supaya Anak Gemar Membaca dan Menulis. 
Jakarta: PT. Masmedia

Suwarsih, Madya. 1994. Panduan Penelitian Tindakan. Yogyakarta : Lembaga Penelitian IKIP Yogyakarta.

Von Seckorc and Guthrie, John T. 2000. Effect of Integrated Instruction Motivation and Strategi Use in Reading

Wigfield and Guthrie, Jhon T. 2000, Enggement and Motivation in Reading 